\title{
Optimization of Immobilized Aldose Reductase Isolated from Bovine Liver
}

\section{Sığır Karaciğerinden İzole Edilen İmmobilize Aldoz Redüktazın Optimizasyonu}

\author{
(D) Marya Vakıl NASLIYAN, (D) Sidar BEREKETOĞLU, (D) Özlem YILDIRIM* \\ Ankara University, Faculty of Science, Department of Biology, Ankara, Turkey
}

\begin{abstract}
Objectives: Isolation of enzymes and experiments on them require great effort and cost and are time-consuming. Therefore, it is important to extend the usability of the enzymes by immobilizing them. In this study our purpose was to immobilize the enzyme aldose reductase (AR) and to optimize the experimental conditions of the immobilized AR and compare them to those of free AR.

Materials and Methods: AR was isolated from bovine liver and the enzyme immobilized in photographic gelatin by cross-linking with glutaraldehyde. Then the optimum conditions for free and immobilized AR in terms of $\mathrm{pH}$, temperature, and storage were characterized by determining the enzyme activity.

Results: Following immobilization, the optimum pH and temperature levels for free $\mathrm{AR}$, which were $\mathrm{pH} 7.0$ and $60^{\circ} \mathrm{C}$, slightly altered to $\mathrm{pH} 7.5$ and $50^{\circ} \mathrm{C}$. The enzyme activity of the immobilized AR was maintained at about $65 \%$ after reusing 15 times. Moreover, immobilized AR maintained $95 \%$ of its original activity after 20 days of storage at $4^{\circ} \mathrm{C}$, while the retained activity of the free AR was $85 \%$ of the original.

Conclusion: Our experiments indicated that the conditions that affect enzyme activity might alter following immobilization. Once the optimum experimental conditions are fixed, the immobilized AR can be stored and reused with efficiency higher than that of free AR. Moreover, this study provides an insight into the advantages of using immobilized AR in enzyme assays rather than free AR.
\end{abstract}

Key words: Aldose reductase, isolation, immobilization

Öz

Amaç: Enzim izolasyonu ve enzimler üzerinde yapılan deneyler, büyük çaba, maliyet ve zaman gerektirir. Bu yüzden, enzimlerin kullanılabilirliğinin immobilizasyon ile uzatılması önemlidir. Bu çalışmadaki amacımız, aldoz redüktaz (AR) enzimini immobilize etmek ve serbest AR'ninkiler ile karşılaştırarak immobilize AR'nin deney şartlarını optimize etmektir.

Gereç ve Yöntemler: AR, sığır karaciğer ve böbreğinden izole edildi ve gluteraldehid ile fotografik jelatine çapraz bağlanarak immobilize edildi. Daha sonra, enzim aktivitesi belirlenerek serbest ve immobilize AR'nin optimum pH, sıcaklık ve depolama koşulları tespit edildi.

Bulgular: Serbest AR için pH 7.0 ve $60^{\circ} \mathrm{C}$ olan optimum pH ve sıcaklık seviyeleri, immobilizasyondan sonra pH 7.5 ve $50^{\circ} \mathrm{C}$ olarak belirlendi. İmmobilize AR'nin enzim aktivitesinin, 15 kez kullanımdan sonra \%65 oranında korunduğu tespit edildi. Bununla birlikte, $+4^{\circ} \mathrm{C}^{\prime}$ de 20 gün boyunca saklanan serbest AR'nin aktivitesi \%85 oranında korunurken immobilize AR'nin aktivitesinin \%95 oranında korunduğu bulunmuştur.

Sonuç: Deneylerimiz, immobilizasyonu takiben enzim aktivitesini etkileyen koşulların değişebileceğini göstermektedir. Ayrıca, immobilize AR, serbest AR'ye göre daha yüksek aktiviteyle korunup tekrar tekrar kullanılabilmektedir.

Anahtar kelimeler: Aldoz redüktaz, izolasyon, immobilizasyon

*Correspondence: E-mail: ozlem.e.yildirim@science.ankara.edu.tr, Phone: +90 5324716046 ORCID-ID: orcid.org/0000-0002-7529-9786

Received: 28.02.2018, Accepted: 29.03.2018

๑Turk J Pharm Sci, Published by Galenos Publishing House. 


\section{INTRODUCTION}

Aldose reductase (AR) (EC 1.1.1.21) is expressed by the AKR1B1 gene in humans. It is located on the 7q35 chromosome, consists of 315 amino acids, and its molecular weight is $36 \mathrm{kD}$. AR is a cytosolic monomeric protein. It specifically catalyzes the polyol pathway, which includes the conversion of glucose-bound nicotinamide adenine dinucleotide phosphate (NADPH) cofactor to sorbitol.,23 Moreover, it reduces the activity of aldehydes such as glutathione complexes. ${ }^{4}$ Indeed, AR is crucial in the detoxification of lipid aldehydes produced by oxidative stress. ${ }^{5}$

Under optimum conditions, enzymes are able to display their activities outside of their natural environment. Using this feature, they can be employed on a large scale in health science, such as in the diagnosis and treatment of diseases and drug design. However, their structure tends to alter during the experimental process. Therefore, studies aim to improve the conformational stability of enzymes. ${ }^{6}$ Immobilization is a method reducing disruption of the enzyme structure. Enzyme immobilization avoids the majority of the instability and loss of enzyme activity. This provides a longer time and flexibility to work on enzymes. Immobilization is not only useful to maintain the stability of biomolecules but also it reduces the cost of enzyme studies.

In the present study for the first time AR was isolated from bovine liver, immobilized, and characterized with respect to several kinetic properties. In addition, AR derived from bovine kidney was used as a side control and simultaneously applied to identical experiments. The AR enzymes from both sources were immobilized in gelatin by glutaraldehyde and washed to remove the free enzyme. We compared the behavior of the free and the immobilized AR under different conditions of $\mathrm{pH}$, temperature, reusing, and storage. The difference in optimum conditions of the free and the immobilized enzyme may be due to alterations in the structure caused by several factors such as carrier material, immobilization method, and activation method. ${ }^{7}$ Indeed it was previously indicated that immobilization significantly changes the conformation of enzymes and thus their activity. ${ }^{8}$

\section{MATERIALS AND METHODS}

\section{Chemical materials}

In this research, ethylenediaminetetraacetic acid (EDTA), $\mathrm{NADPH}$, and lithium sulfate $\left(\mathrm{Li}_{2} \mathrm{SO}_{4}\right)$ were purchased from Gerbu, Germany. Ammonium sulfate was supplied by Merck. Phenylmethylsulfonyl fluoride (PMSF), DL-glyceraldehyde, and all other materials used were analytically graded and obtained from Sigma Aldrich, Germany.

\section{Isolation of AR enzyme from bovine liver}

The bovine liver was provided by a slaughterhouse in Kazan, Ankara, Turkey. Small pieces of liver samples were washed with $1.0 \mathrm{mM}$ EDTA. Then they were measured and homogenized with threefold $1.0 \mathrm{mM}$ EDTA and $50 \mu \mathrm{M}$ PMSF and spun at $+4^{\circ} \mathrm{C}$ and $10,000 \mathrm{rpm}$ for $30 \mathrm{~min}$. To acquire $40 \%$ saturation, $22.6 \mathrm{~g}$ of ammonium sulfate was added to each $100 \mathrm{~mL}$ of supernatant followed by rotation at $10,000 \mathrm{rpm}$ at $+4^{\circ} \mathrm{C}$ for $25 \mathrm{~min}$. To gain $50 \%$ and $75 \%$ saturations, the same method was carried out by adding $5.8 \mathrm{~g}$ and $15.9 \mathrm{~g}$ of ammonium sulfate to the $100 \mathrm{~mL}$ of supernatant solution, respectively. The pellets were dissolved with $50 \mathrm{mM}$ sodium chloride and stored in a freezer at $-80^{\circ} \mathrm{C}$.

\section{Determining the protein amount}

Following isolation, the amount of protein was detected by Bradford assay. ${ }^{9}$ The bovine serum albumin (BSA) standards were used at the concentrations of $0.4,0.6,0.8,1.0,1.2$, and $1.4 \mathrm{mg} / \mathrm{mL}$. BIO-RAD reagent was added to the BSA standards and the sample. Then each solution was measured using a spectrophotometer at $595 \mathrm{~nm}$ wavelength. Finally, protein amount was calculated using the standard graph generated with optical densities of the standards.

\section{Assay of AR enzyme activity}

AR activity was detected against DL-glyceraldehyde, by monitoring the NADPH oxidation to $\mathrm{NADP}^{+}$at $340 \mathrm{~nm} .{ }^{10}$ The reaction mixture consisted of $A R$ enzyme ( $4.54 \mathrm{mg} / \mathrm{mL}$ ), NADPH $\left(9 \times 10^{-5} \mathrm{M}^{2}, \mathrm{Li}_{2} \mathrm{SO}_{4}(320 \mathrm{mM}-400 \mathrm{mM})\right.$, DL-glyceraldehyde $\left(6 \times 10^{-4} \mathrm{M}\right)$, and $\mathrm{KP}$ buffer $\left(50 \mathrm{mM}, \mathrm{pH}\right.$ 6.2). $\mathrm{NADP}^{+}$oxidation was followed in $0.25 \mathrm{~mL}$ of reaction mixture using a multimode microplate reader at $340 \mathrm{~nm}$ for $4 \mathrm{~min}$. Initial and final rates of enzymatic reactions were measured and recorded as nmol/ $\mathrm{min} / \mathrm{mg}$ protein.

\section{Immobilization of AR enzyme}

The immobilization gel consisted of $0.025 \mathrm{~g}$ of photographic gelatin and $0.125 \mathrm{M}$ glutaraldehyde in $0.067 \mathrm{M}$ phosphate tampon solution ( $\mathrm{pH}$ 7.4). The photographic gelatin was prepared at $50^{\circ} \mathrm{C}$ and then cooled to $30-35^{\circ} \mathrm{C}$. Different units of $A R$ enzyme were added to the gelatin and then vortexed. Crosslinking glutaraldehyde was included at the concentration of $5 \times 10^{-5} \mathrm{M}$. Then $100 \mu \mathrm{L}$ of the mixture was placed onto cellulose triacetate. Enzyme and gelatin complexes were dried for $24 \mathrm{~h}$ at room temperature.

The film strips carrying the immobilized AR were assayed for enzyme activity. The reaction mixture consisted of 2.7 $\mathrm{mL}$ of potassium phosphate, $0.1 \mathrm{~mL}$ of $\mathrm{NADPH}$, and $0.1 \mathrm{~mL}$ DL-glyceraldehyde. Absorbance of this reaction mixture was measured at $340 \mathrm{~nm}$ before and after 20 min incubation with the film strips to detect enzyme activity.

\section{RESULTS AND DISCUSSION}

AR isolated from bovine liver was immobilized by crosslinking with glutaraldehyde in photographic gelatin. To detect the amount of AR protein we used the Bradford assay and spectrophotometric measurements. The results indicated that the protein amount was $18.39 \pm 0.09 \mathrm{mg} / \mathrm{mL}$. In the standard group, the activity values for only $A R$ were $4.172 \times 10^{-4} \mathrm{U} / \mathrm{L}$ in liver. These values are accepted as $100 \%$ enzyme activity.

Following immobilization, the free enzyme was removed by washing the film strips three times with phosphate buffer $(0.067 \mathrm{M}, \mathrm{pH} 6.2)$ at $25^{\circ} \mathrm{C}$ for $5 \mathrm{~min}$ and spectrophotometry was used to detect the amount of free enzyme. Using the washed 
film strips, the effect of enzyme concentration on immobilized enzyme activity was tested to detect the immobilized enzyme leakage. Our results showed that AR leakage from the film strips increased with enzyme concentration while the enzyme activity was reduced after each wash. On the other hand, three washes were sufficient to remove the leakage completely (Table 1).

We demonstrated that enzyme leakage increased depending on the increasing enzyme unit. This is because of the constant concentrations of the gelatin and glutaraldehyde. In other words, when there was insufficient gelatin, which is the immobilization medium, and/or glutaraldehyde, which is the cross-linker in the immobilization reaction, there was more unbound AR released from the film strips at high enzyme concentrations.

\section{Characterization of the free and immobilized $A R$}

Conditions of $\mathrm{pH}$, temperature, and storage were optimized to characterize the free and the immobilized AR. Moreover, the effects of storage stability and continual use on the activity of the immobilized strips were tested.

\section{pH}

To evaluate the optimum $\mathrm{pH}$ for the free $\left(1.46 \times 10^{-8} \mathrm{U}\right)$ and the cross-linked $\left(1.56 \times 10^{-8} \mathrm{U}\right) \mathrm{AR}$, we measured the levels of enzyme activity in a $\mathrm{pH}$ gradient between $\mathrm{pH} 4$ and 9 at $25^{\circ} \mathrm{C}$ for $5 \mathrm{~min}$. It was demonstrated that the optimal $\mathrm{pH}$ values for the free and the immobilized AR from liver were respectively 7.0 and 7.5 (Figure 1).

Table 1. Effect of the enzyme concentration on the immobilized AR from liver

\begin{tabular}{|c|c|c|c|}
\hline \multirow{3}{*}{$\begin{array}{l}\text { Enzyme volume } \\
\left(\times 10^{-8} \mathrm{U}\right)\end{array}$} & \multicolumn{3}{|c|}{ Activity (Enzyme unit $/ \mu \mathrm{mol} / \mathrm{min} / \mathrm{L}$ ) } \\
\hline & \multicolumn{3}{|c|}{ Number of washes } \\
\hline & 1 & 2 & 3 \\
\hline 1.04 & 0.017 & 0.007 & 0.000 \\
\hline 1.46 & 0.130 & 0.015 & 0.000 \\
\hline 2.08 & 0.347 & 0.024 & 0.000 \\
\hline
\end{tabular}

AR: Aldose reductase

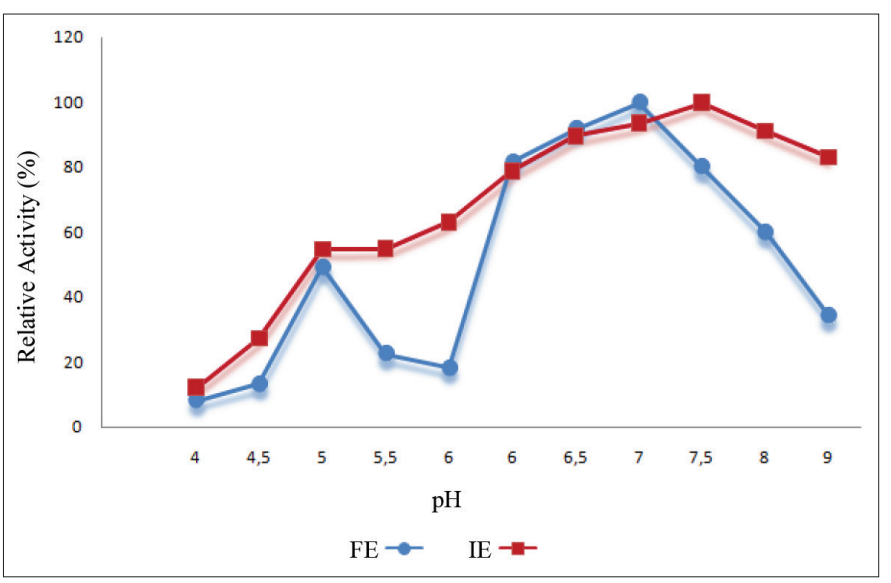

Figure 1. The enzyme activity levels of the free (FE) and the immobilized (IE) AR enzyme from liver according to $\mathrm{pH}$

AR: Aldose reductase
We observed that the optimum $\mathrm{pH}$ for AR shifted to 7.5 from 7.0 upon immobilization. This alteration should be because of the $\mathrm{H}^{+}$and the $\mathrm{OH}^{-}$ions that are released into the microenvironment during the reaction. Indeed, this result about the optimum $\mathrm{pH}$ alteration was expected because of the context of the environments of free and immobilized enzymes as previously indicated." Moreover, previous studies showed that the optimum $\mathrm{pH}$ of the enzyme was changed by the polar groups of gelatin during the immobilization. ${ }^{12}$ There are possible interactions such as hydrogen bonds that are generated between enzyme and polymer carrier. ${ }^{13}$ However, the immobilization might not significantly affect the stability of optimum $\mathrm{pH}$ for enzymes in some cases. For instance, NADH-cytochrome b5 reductase enzyme was isolated from rabbit liver microsomes and it was immobilized in photographic gelatin by chemical cross-linking using chromium (III) acetate. The experiments showed that the optimum $\mathrm{pH}$ for the free and the immobilized enzyme was in the range from 6.1 to $7.5 .^{14}$ Similarly, the free and the immobilized $\beta$-galactosidase on the gelatin carboxymethylcellulose carrier were assayed for the optimum $\mathrm{pH}$. It was observed that immobilization of $\beta$-galactosidase did not have any significant effect on $\mathrm{pH}$ stability. ${ }^{15}$ Consequently, it can be foreseen that the values of optimum $\mathrm{pH}$ for free and immobilized enzyme can change; however, this might not be the case for all enzymes and immobilization methods.

\section{Temperature}

We aimed to uncover the difference between optimum temperatures for the free and the immobilized AR, which is important for enzyme activity. To detect the optimum temperatures, activity of the enzyme was tested at different levels ranging from $5^{\circ} \mathrm{C}$ to $70^{\circ} \mathrm{C}$. The highest enzyme activity was observed at $60^{\circ} \mathrm{C}$ for the free AR from liver and this shifted to $50^{\circ} \mathrm{C}$ after the cross-link immobilization (Figure 2).

These results suggested that the immobilization of $A R$ from liver reduces the optimum temperature. However, in our experiments we also showed that immobilization increased the thermal stability of the enzyme between $60^{\circ} \mathrm{C}$ and $70^{\circ} \mathrm{C}$ (Figure

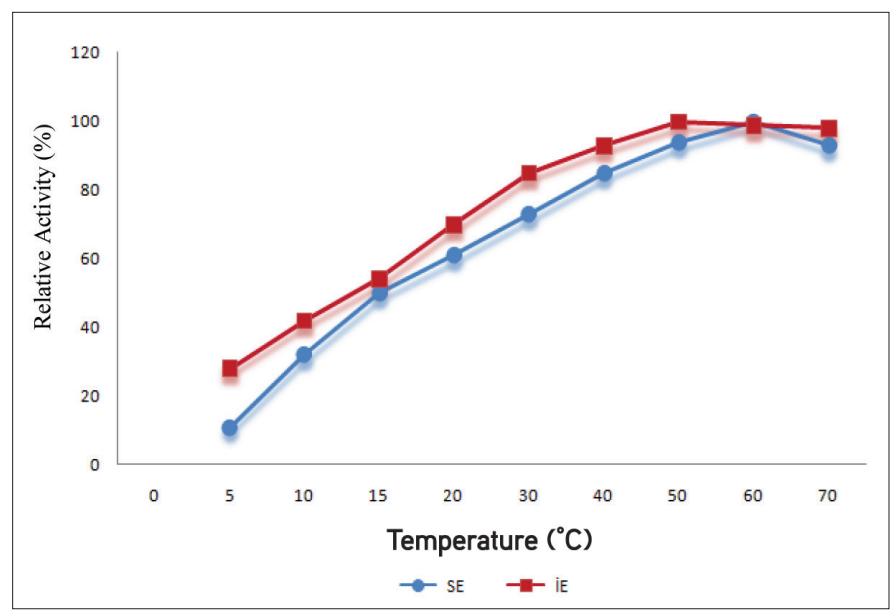

Figure 2. The enzyme activity levels of the free and the immobilized AR from liver according to temperature

AR: Aldose reductase 
2). These results indicated that immobilization generated an optimum temperature range from $50^{\circ} \mathrm{C}$ to $70^{\circ} \mathrm{C}$, while free enzyme showed the highest activity only at $60^{\circ} \mathrm{C}$. In other words, immobilization maintained enzyme stability against increasing temperature. It was previously demonstrated that the optimum temperature of $\mathrm{NADH}$-cytochrome b5 reductase enzyme from rabbit was $30^{\circ} \mathrm{C}$, while it decreased to $25^{\circ} \mathrm{C}$ upon cross-link immobilization of the enzyme. ${ }^{14}$ Conversely, free $\beta$-galactosidase showed the highest enzyme activity at $47^{\circ} \mathrm{C}$, while it was at $57^{\circ} \mathrm{C}$ after the enzyme was cross-linked to the gelatin carboxymethlyselulose carrier. ${ }^{15}$ This might suggest that the carrier system protects the immobilized enzyme from thermal denaturating.

\section{Reusing}

To test the activity of the reused $A R$, it was immobilized in photographic gelatin with glutaraldehyde at $5 \times 10^{-8} \mathrm{M}$ concentration. Upon reusing the immobilized AR from liver $\left(1.46 \times 10^{-8} \mathrm{U}\right) 15$ times a day at $25^{\circ} \mathrm{C}, 65 \%$ of its original activity was recovered (Figure $3 a$ ). Similarly, we applied the same

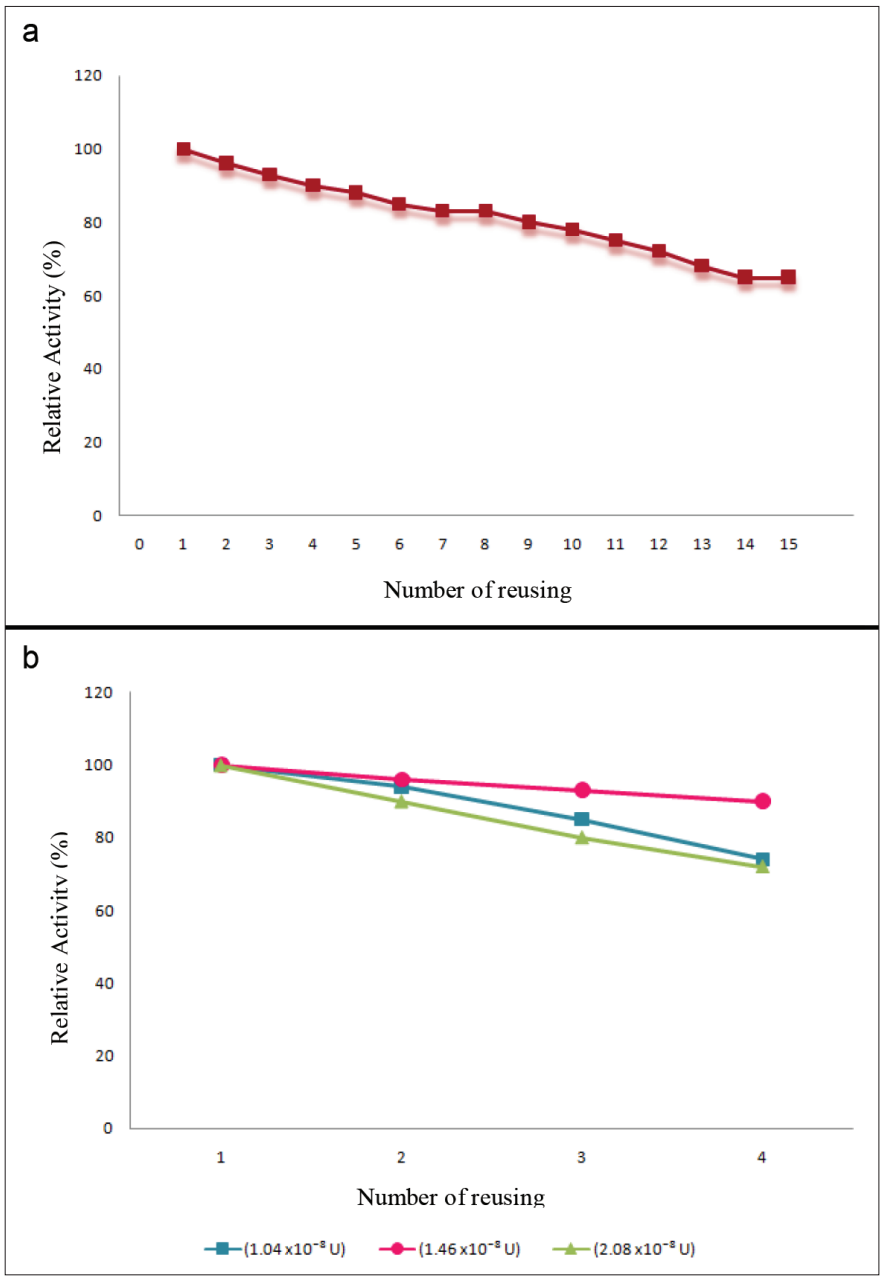

Figure 3. a) The enzyme activity levels of the immobilized AR from liver $\left(1.46 \times 10^{-8} \mathrm{U}\right)$ according to reusing stability. b) The enzyme activity levels of the immobilized AR from liver $\left(1.04 \times 10^{-8} \mathrm{U}\right)$ and $\left(1.46 \times 10^{-8} \mathrm{U}\right)\left(2.08 \times 10^{-8} \mathrm{U}\right)$ according to reusing stability

AR: Aldose reductase approach to different concentrations of the immobilized AR in different conditions. For instance, the immobilized $A R$ from liver at the concentration of $2.08 \times 10^{-8} \mathrm{U}$ conserved $35 \%$ of the beginning enzyme activity after being used 10 times at $25^{\circ} \mathrm{C}$ (data not shown). We also tested the immobilized AR from liver for concentrations at $1.04 \times 10^{-8} \mathrm{U}, 1.46 \times 10^{-8} \mathrm{U}$, and $2.08 \times 10^{-8} \mathrm{U}$ after being reused 4 times and reported that its activity was conserved about $74 \%, 90 \%$, and $72 \%$, respectively (Figure $3 \mathrm{~b}$ ).

\section{Storage}

To evaluate the effect of storage period on enzyme activity, we stored the free and immobilized $A R$ at $4^{\circ} \mathrm{C}$ for 20 days and at $25^{\circ} \mathrm{C}$ for 10 days. After 20 days of storage at $4^{\circ} \mathrm{C}$, activity of the immobilized AR was $95 \%$ of its original activity from liver (Figure 4a). Moreover, the free and the immobilized liver AR preserved $54 \%$ and $78 \%$ of their enzyme activity capacities following storage at $25^{\circ} \mathrm{C}$ for 10 days (Figure $4 \mathrm{~b}$ ).

Enzyme stability during storage is an important parameter for enzyme studies. Although it is expected that enzyme activity will be lower than at the beginning, the decrease should be minimized. This impairment in activity is most probably because of the denaturation of the enzyme structure. ${ }^{16}$ In Yıldırım et al. ${ }^{14}$
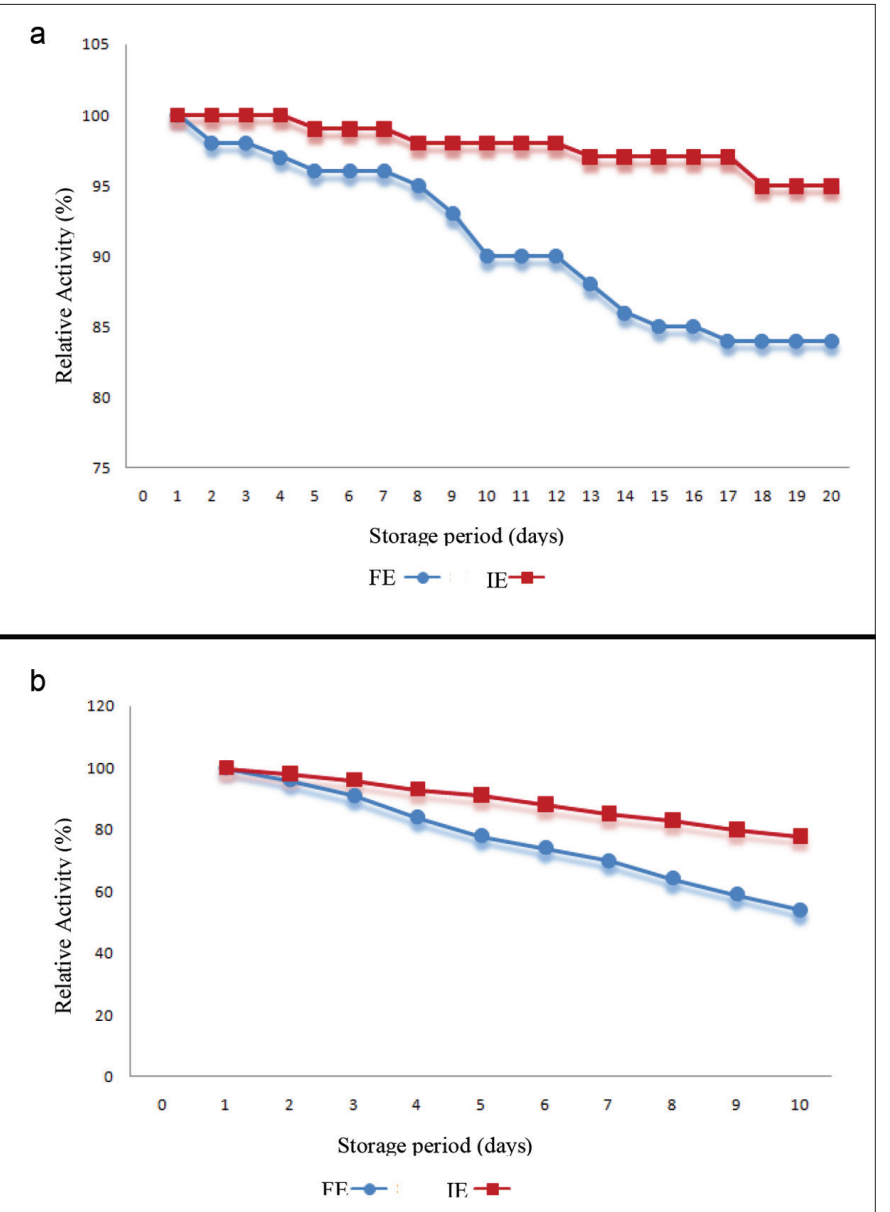

Figure 4. a) The enzyme activity levels of the immobilized AR from liver according to storage stability at $4^{\circ} \mathrm{C}$. b) The enzyme activity levels of the immobilized AR from liver according to storage stability at $25^{\circ} \mathrm{C}$

AR: Aldose reductase 
research the free and the immobilized NADH-cytochrome b5 reductase enzymes were compared for their activities after 60 days of storage at $-7^{\circ} \mathrm{C},+4^{\circ} \mathrm{C}$, and $+25^{\circ} \mathrm{C}$. They recorded that immobilization protects activity of the stored enzyme with higher efficiency at high temperature $\left(+25^{\circ} \mathrm{C}\right)$ than at lower temperatures $\left(-7^{\circ} \mathrm{C}\right.$ and $\left.+4^{\circ} \mathrm{C}\right) .^{14}$ Similarly, Kim et al. ${ }^{6}$ showed that immobilized lipase enzyme maintained $82 \%$ of its activity after 30 days at room temperature, while the free lipase lost its activity completely. These results suggested that immobilization is a good tool to protect enzyme activity against temperature increases during storage. The efficiency of immobilization can be increased by carrying out the immobilization in a specific manner. For instance, it was demonstrated that the aldo/keto reductase AKR1A1 was immobilized as specific-oriented and so it was surface-bound. On the other hand, the unspecific immobilization was adsorptive; therefore, it showed less activity relative to the specifically immobilized aldo/keto reductase AKR1A1. ${ }^{17}$

The present study showed that immobilized AR enzyme can be preferable to work with than the free one. Our results showed that enzyme activity is retainable following immobilization as long as the experimental conditions are specifically fixed according to the immobilized AR.

\section{CONCLUSIONS}

Consequently, we indicated that immobilization is a convenient method to utilize the enzyme AR in multiple experiments. While free enzymes can be used only once in experiments, immobilized enzymes can be used several times due to the protective features of glutaraldehyde cross-linking. In this case, optimal conditions for the immobilized AR should be indicated and applied to the experiments since these conditions might be different from those of the free AR.

Conflict of Interest: No conflict of interest was declared by the authors.

\section{REFERENCES}

1. Ramana KV, Srivastava SK. Aldose reductase: A novel therapeutic target for inflammatory pathologies. Int J Biochem Cell Biol. 2009;42:17-20.

2. Petrash JM. All in the family: Aldose reductase and closely related aldoketo reductases. Cell Mol Life Sci. 2009;61:737-749.

3. Reddy GB, Satyanarayana A, Balakrishna N, Ayyagari R, Padma M, Viswanath K, Petrash JM. Erythrocyte aldose reductase activity and sorbitol levels in diabetic retinopathy. Mol Vis. 2008;14:593-601.
4. Srivastava S, Chandra A, Bhatnagar A, Srivastava SK, Ansari NH. Lipid peroxidation product, 4-hydroxynonenal and its conjugate with GSH are excellent substrates of bovine lens aldose reductase. Biochem Biophys Res Commun. 1995;217:741-746.

5. Srivastava SK, Ramana KV, Bhatnagar A. Role of aldose reductase and oxidative damage in diabetes and the consequent potential for therapeutic options. Endocr Rev. 2005;26:380-392.

6. Kim M, Park JM, Um HJ, Lee DH, Lee KH, Kobayashi F, Iwasaka Y, Hong $\mathrm{CS}$, Min J, Kim YH. Immobilization of cross-linked lipase aggregates onto magnetic beads for enzymatic degradation of polycaprolactone. $J$ Basic Microbiol. 2010;50:218-226.

7. Yemul O, Imae T. Covalent-bonded immobilization of lipase on poly (phenylene sulfide) dendrimers and their hydrolysis ability. Biomacromolecules. 2005;6:2809-2814.

8. Atia KS, Ismail SA, Dessouki AM. Immobilization of $\beta$-amylase using polyacrylamide polymer derivatives. J Chem Technol Biotechnol. 2003;78:891-898.

9. Bradford MM. A rapid and sensitive method for the quantitation of microgram quantities of protein utilizing the principle of protein-dye binding. Anal Biochem. 1976;72:248-254.

10. Hayman S, Kinoshita JH. Isolation and properties of lens aldose reductase. J Biol Chem. 1965;2:240.

11. Hasırcı N, Aksoy S and Tümtürk $\mathrm{H}$. Activation of poly(dimer acid-co alkylpolyamine) particles for covalent immobilization of a-amylase. React Funct Polym. 2006;66:1546-1551.

12. Emregül $E$, Sungur $S$, Akbulut U. Immobilization of glucose oxidase onto gelatin for biosensor construction. J Biomater Sci Polym Ed. 2009;16:505-519.

13. Chen KC, Wu JY. Substrate protection of immobilized glucose isomerase. Biotechnol Bioeng. 1987;30:817-824.

14. Yıldırım Ö, Akbulut $U$, Arınç E, Sungur S. Immobilization of NADHcytochrome b5 reductase into gelatin by crosslinking. Macromolecular Reports. 1994;31:19-28.

15. Sungur S, Yıldırım Ö. Batch and continuous hydrolysis of lactose using $\beta$-galactosidase immobilized on gelatin-CMC. Polym Plast Technol Eng. 1999;38:821-829.

16. Chellapadian M. Preparation and characterization of alkaline protease immobilized on vermiculite. Process Biochem. 1997;33:169-173.

17. Holland-Nell K, Beck-Sickinger AG. Specifically immobilized aldo/keto reductase AKR1A1 shows a dramatic increase in activity relative to the randomly immobilized enzyme. Chembiochem. 2007;8:1071-1076. 